\title{
The Impact of Digitalization Risks on the Business Processes of an
} Insurance Company

\author{
Anna Faizova \\ Faculty of Economics \\ Saint-Petersburg State University \\ Saint-Petersburg, Russia \\ a.faizova@spbu.ru \\ Svetlana Kalayda \\ Faculty of Economics \\ Saint-Petersburg State University \\ Saint-Petersburg, Russia \\ s.kalayda@spbu.ru
}

\author{
Irina Malova \\ Bank of Russia \\ Saint-Petersburg, Russia \\ cadeau90210@yandex.ru
}

\author{
Ekaterina Solopenko \\ Faculty of Economics \\ Saint-Petersburg State University \\ Saint-Petersburg, Russia \\ e.solopenko@spbu.ru
}

\begin{abstract}
Nowadays digitalization is one of the key drivers of insurance market development in Russia. Introducing InsurTech provides insurance companies with a number of competitive advantages, such as increasing speed of making decisions, opportunities for portfolio expansion, tools for risk assessment and fraud detection. Application of digital technologies helps them to increase effectiveness of business processes. Among all business processes of an insurance company we emphasize the most significant in terms of insurance service provision. Those include the processes of underwriting, conclusion and support of an insurance contract, settlement of an insured event. However, adoption of innovations blurs borders between business processes. The paper discusses InsurTech tools implemented in these business processes, evaluates the effectiveness of their use, identifies the associated risks. The conclusion is made that the risk of unauthorized access or use of personal data is the most significant. Another significant risk is the model risk arising from the imperfection of the models used, insufficient data or its poor quality. In addition to that, the impact of digitalization on the activities of insurance companies and its business processes should not be overestimated. Funding: The reported study was funded by RFBR, project number 20-01-00785.
\end{abstract}

Keywords: insurance, business processes, digitalization, InsurTech

\section{INTRODUCTION}

Being a socio-economic mechanism and an accumulator of investment resources, the national insurance market is one of the most significant segments of not only the financial market, but also the entire market economy. However, the level of the Russian insurance market remains not high enough when compared to developed countries. Nowadays digitalization is one of the effective directions of its modernization [1]. Tsyganov, Bryzgalov conclude that the development of the insurance market substantially depends on the introduction of new technologies of the digital economy, which affect the insurance technology, but do not change its economic nature [2]. At the same time, digital technologies (InsurTech) are introduced less rapidly in insurance than in other areas of the financial sector of the economy, which is associated primarily with the traditional conservatism of insurance companies.

Application of InsurTech tools gives insurance companies a number of benefits. E.g. Cappiello notes the key importance of digital transformation as a strategic development priority while analyzing the role of innovative technologies in increasing the competitiveness of insurance companies [3]. Introduction of digital technology will increase the speed of decision-making in all business processes of the insurer. Cortis, Debattista, Debono, Farrell [4] believe that InsurTech allows the development of new personalized insurance products that meet modern customer needs. The introduction of digital technology allows the insurance company to expand its portfolio by taking specific risks, working with new segments and attracting insurers. Thus, in developing countries the use of mobile technologies is especially significant when promoting insurance [5]. Another advantage of using InsurTech is the ability to take into account real data to build a more accurate and individual assessment of risks taken by insurance [6], [7]. In addition to the said above, modern technology provides better opportunities for fraud detection and risk management of insurance companies [8].

However, despite the high activity of researchers in considering the InsurTech market, issues of studying ambiguous effect of digitalization, and, in particular, the risks associated with introducing new technologies into various business processes, still remain insufficiently developed.

\section{Problem Statement}

The task of identifying those business processes of the insurance company, for which the implementation of InsurTech can have the greatest positive effect depending on the goals of such implementation, arises due to necessity of a balanced development of the Russian insurance market under the influence of the widespread adoption of digital technologies. Besides, the issue of the use of digital technologies in the insurance industry should be 
accompanied not only by evidence and evaluation of the effectiveness of the use of a particular tool, but also by the identification and analysis of the risks associated with the introduction of such technologies for both the insurance company and its clients. This study is aimed at studying these issues.

\section{RESEARCH METHODS}

The research was carried out as follows. First, the main business processes of the insurance company that are directly related to the adoption of insurance risk (business processes of underwriting and signing an insurance contract) and provision of insurance service (business process of loss settlement) were identified. Then digital technologies that can be implemented in these business processes, as well as the advantages of their use were analyzed. Finally the risks of digitalization implementation were identified for each business process.

\section{RESULTS AND DISCUSSION}

Activities of an insurer can be represented by a set of business processes [9]. The key business processes in the course of implementation and provision of insurance services are: underwriting, conclusion and support of an insurance contract, loss settlement. Modern digital technologies are actively used in every business process, reducing the costs of insurance companies on the one hand, and increasing the attractiveness of insurance products for customers on the other. However, introduction of InsurTech tools brings new risks, analysis of which is an extremely important task nowadays.

Underwriting is a risk assessment process for making a decision whether to sign an insurance contract or not and determining a fair insurance premium. Traditionally, such an assessment is made on the basis of historically accumulated statistical data on similar objects. The implementation of InsurTech makes it possible to construct such estimates based on real data, simplify risk assessment procedures and make them more accurate [10]. BigData and AI (Artificial Intelligence) technologies allow you to modify existing risk assessment techniques, increasing their accuracy. Telematics, wearables and IoT (Internet of Things) enable insurers to collect a large amount of real customer data used to build an individual risk assessment.

The business process of conclusion an insurance contract (and here we assume not only the fact of signing the insurance contract, but also the process of selling the insurance product) is associated with rather large expenses of the insurer for its implementation. These are expenses for: services of insurance intermediaries, paper forms of insurance contracts, rental of sales offices, labor of employees who consult clients and execute contracts, etc. InsurTech tools provide opportunities to reduce these costs, and, as a result, reduce the cost of insurance for a client. Chatbots and mobile applications are used to automate interaction with policyholders. This greatly simplifies the process of conclusion a contract for the insured, reduces the time for its execution, and eliminates the insurance intermediary from the sales chain, thus reducing the costs of the insurer.

Mobile and Internet technologies also help insurance companies to increase the efficiency of intermediaries, primarily insurance agents, by providing them remote access to certain data of the insurer's corporate information system. Using these tools, insurance agents can register, draw up insurance contracts and pay an insurance premium. Using AI to identify the needs of the insured, the insurer will be able to develop cross-selling more actively.

The process of support a contract consists of making changes and various adjustments to the current insurance contract, mainly at the initiative of the insured. Mobile applications and websites make the insurer available 24/7. This allows customers to notify the insurance company about the risk change under the contract online, and the insurance company makes it possible to promptly make changes to the insurance contract and advise the client on issues of his insurance. In addition to that, AI technologies help insurers to predict the possibility of extension of the contract and cross-sales at the stage of conducting an insurance contract. Telematics, wearables and IoT enable the insurer to monitor condition of the insured object in real time, control the level of risk and even give recommendations for reducing it.

Loss settlement is essentially one of the most important business processes of an insurance company, which includes steps from receiving an application for an insured event to making an insurance payment. A company that organizes it most conveniently for customers receives significant competitive advantages. Modern digital technologies contribute to the implementation of this principle [11]. Mobile applications allow a client to file a loss claim without visiting an office of an insurance company; telematics, wearables and IoT make it possible to establish the occurrence of an insured event; AI algorithms conduct an initial damage assessment [12], modern software reduces the use of human labor in processing claims and can be used for making an automatic decision on an insured event. When providing insurance services for voluntary medical insurance, insurance companies use medical chatbots that can recognize the main symptoms of the disease and guide the client to an appropriate specialist when an insured event occurs.

The use of modern technologies also equips insurance companies with new tools to detect cases of fraud [13]. E.g. the use of AI allows to identify suspicious claims and falsified documents, cloud and mobile technologies make it possible to obtain information about duplicate or overestimated claims, inconsistency of data of the insured, etc. in real time.

However, in addition to the obvious benefits, digital technologies also pose new risks. Introduction of IoT technologies is perceived as a serious invasion of privacy, since they can be considered as a tool for obtaining personal data about a client [14]. For example, installing appropriate telematics devices on a car will give the insurer an opportunity to obtain data on the vehicle's travel routes, policyholder's preferences, mode of his day, etc. Thus, the use of telematics, wearables and IoT entails the risk of unauthorized access to and use of personal data. The task of ensuring the confidentiality of consumers and their personal data during the implementation of InsurTech is of great importance.

The use of AI technologies allows the insurer to conduct an individual assessment of the risk taken on insurance and 
reduce the risks of fraud, but their use can lead to unreliable results due to modeling errors or poor data quality, including the case of data lack. The use of mobile technologies leads to the insurer's additional risk of incorrect data input by the insured, either intentionally or not. Risks of the impact of the introduction of digitalization in individual business processes of the insurer are briefly presented in the table 1 below.

It is worth noting the presence of potential gaps in the existing regulatory framework governing the activities of insurance intermediaries in the implementation of InsurTech. The use of modern technologies, such as comparison websites and provision of robo-advice, entails the need to create rules that protect customers in relations with digital intermediaries [15].

TABLE I. SUMMARY OF USING DIGITAL TECHNOLOGIES IN BUSINESS PROCESSES OF INSURANCE COMPANY AND ASSOCIATED RISKS

\begin{tabular}{|c|c|c|c|c|}
\hline & \multicolumn{4}{|c|}{ Business processes of insurance company } \\
\hline & $\begin{array}{c}\text { Underwritin } \\
g\end{array}$ & $\begin{array}{c}\text { Conclusion } \\
\text { and selling } \\
\text { of an } \\
\text { insurance } \\
\text { contract }\end{array}$ & $\begin{array}{c}\text { Support of } \\
\text { an } \\
\text { insurance } \\
\text { contract }\end{array}$ & $\begin{array}{c}\text { Settlement } \\
\text { of an } \\
\text { insured } \\
\text { event }\end{array}$ \\
\hline $\begin{array}{l}\text { InsurTech } \\
\text { tools }\end{array}$ & $\begin{array}{l}\text { Telematics, } \\
\text { wearables, } \\
\text { Internet of } \\
\text { Things } \\
\text { BigData } \\
\text { Artificial } \\
\text { Intelligence }\end{array}$ & $\begin{array}{l}\text { Chatbots } \\
\text { Mobile } \\
\text { application } \\
\mathrm{s} \text { and } \\
\text { websites } \\
\text { Artificial } \\
\text { Intelligence }\end{array}$ & $\begin{array}{l}\text { Mobile } \\
\text { application } \\
\text { s and } \\
\text { websites } \\
\text { Artificial } \\
\text { Intelligence }\end{array}$ & $\begin{array}{l}\text { Mobile } \\
\text { application } \\
\mathrm{s} \text { and } \\
\text { websites } \\
\text { Telematics, } \\
\text { wearables, } \\
\text { Internet of } \\
\text { Things } \\
\text { Artificial } \\
\text { Intelligence }\end{array}$ \\
\hline Risk & $\begin{array}{l}\text { Risk of } \\
\text { unauthorize } \\
\text { d use of } \\
\text { personal } \\
\text { data } \\
\text { Model Risk } \\
\text { Data Risk }\end{array}$ & $\begin{array}{l}\text { Fraud Risk } \\
\text { Risk of } \\
\text { incorrect } \\
\text { data entry }\end{array}$ & $\begin{array}{l}\text { Model Risk } \\
\text { Data Risk } \\
\text { Risk of } \\
\text { incorrect } \\
\text { data entry }\end{array}$ & $\begin{array}{l}\text { Risk of } \\
\text { unauthorize } \\
\text { d use of } \\
\text { personal } \\
\text { data } \\
\text { Model Risk } \\
\text { Fraud Risk } \\
\text { Data Risk }\end{array}$ \\
\hline
\end{tabular}

\section{CONCLUSION}

The introduction of technological innovations in the insurance industry is a trend of recent years. Using InsurTech benefits both insurance companies and their customers. Digitalization improves the quality of insurance services due to the individual approach to each client at all business processes of the insurance company and leads to broadening the range of insurance products and insurance settlement mechanisms (taking into account various requests and opportunities). When introducing innovations, the boundaries of business processes are partially blurred, in particular, the processes of underwriting and conclusion of an agreement (sale) are considered only in close interaction, and possibly in a combination.

However, the use of digital technologies in the insurance industry entails additional risks for both the insurance company and its customers. First of all, we are talking about the risk of unauthorized access or use of personal data. The need to ensure consumer confidentiality and their personal data creates an additional burden for insurance companies, which is especially hard for small insurance companies that do not have sufficient resources and technologies.
Another significant risk is the model risk arising from the imperfection of the models used, insufficient data or its poor quality. In order to reduce this risk, it makes sense for insurance companies to constantly monitor the effectiveness of the digital technologies, models and techniques used in each business process.

In addition, the impact of digitalization on the activities of insurance companies and its business processes should not be overestimated. Firstly, it is necessary to carefully weigh the costs of implementing appropriate technologies and its final economic effect. And secondly, there are several stages of individual business processes where artificial intelligence cannot replace a human at the moment.

\section{Acknowledgment}

The reported study was funded by RFBR, project number 20-01-00785.

\section{References}

[1] E. Nebolsina, "Peculiarities of insurtech development in the USA, the UK, China and Russia", Proceedings of the 32nd International Business Information Management Association Conference, IBIMA 2018 - Vision 2020: Sustainable Economic Development and Application of Innovation Management from Regional Expansion to Global Growth, pp. 3509-3516, 2018.

[2] A.A. Tsyganov and D.V. Bryzgalov, "Cifrovizaciya strahovogo rynka: zadachi, problem I perspektivy", Digitalization of the insurance market: tasks, problems and prospects, Ekonomika. Nalogi. Pravo, 2, pp.111-120, 2018 (in Russian).

[3] A. Cappiello, Technology and the Insurance Industry: Reconfiguring the Competitive Landscape. Springer, Cham., 119 p., 2018. DOI: 10.1007/978-3-319-74712-5.

[4] D. Cortis, J. Debattista, J. Debono, and M. Farrell, "InsurTech", In: T. Lynn, J.G. Mooney, P. Rosati, M. Cummins, (Eds), Disrupting Finance: Fintech And Strategy In The 21st Century, Palgrave Pivot, England, pp. 71-84, 2019.

[5] N.G. Adamchuk, "Razvitie mobilnogo straxovaniya v razvivayushhixsya stranax", Development of mobile insurance in developing countries, Strahovoe delo, vol. 11, pp. 15-18, 2018 (in Russian).

[6] L. McFall and L. Moor, "Who, or what, is InsurTech personalizing?: persons, prices and the historical classifications of risk", Distinktion: Journal Of Social Theory, vol. 19, SI, pp. 193-213, 2018. DOI: 10.1080/1600910X.2018.1503609.

[7] A.G. Rumson and S.H. Hallett, "Innovations in the use of data facilitating insurance as a resilience mechanism for coastal flood risk", Sci. Total Environ., 661, pp. 598-612, 2019. DOI: 10.1016/j.scitotenv.2019.01.114.

[8] T.C. Yan, P. Schulte, and D.L.K. Chuen, "InsurTech and FinTech: Banking and Insurance Enablement", In: Handbook of Blockchain, Digital Finance, and Inclusion, Cryptocurrency, FinTech, InsurTech, and Regulation, vol. 1, pp. 249-281, 2017. DOI: 10.1016/B978-0-12810441-5.00011-7.

[9] S.A. Kalayda, "Biznes-process po formirovaniu i ispolzovaniu strahovyh rezervov", Business process on formation and use of insurance reserves, Vestnik Sankt-Peterburgskogo universiteta, Ekonomika, vol. 5, no. 2, pp. 99-106, 2012 (in Russian).

[10] E. Stoeckli, C. Dremel, and F. Uebernickel, "Exploring characteristics and transformational capabilities of InsurTech innovations to understand insurance value creation in a digital world", Electronic Markets, vol. 28 (3), pp. 287-305, 2018. DOI: 10.1007/s12525-018-0304-7.

[11] A.B. Znamensky and S.B. Bogoyavlensky, "InsurTech: oblasti primeneniya pervye rezultaty I perspektivy vnedreniya", InsurTech: areas of application, first results and prospects of implementation, Finansy, vol. 2, pp. 34-39, 2018 (in Russian). 
[12] F. Corea, How AI Is Changing the Insurance Landscape. In: Applied Artificial Intelligence: Where AI Can Be Used In Bussiness. SpringerBriefs in Complexity, Springer, Cham, pp 5-10, 2019. DOI: 10.1007/978-3-319-77252-3_2.

[13] I.B. Kotlobovsky and N.V. Kirichenko, "Innovacionnye informacionnye tehnologii dlya strahovoy otrasli”, Innovative information technologies for the insurance industry, Finansy, vol. 9, pp. 38-44, 2017 (in Russian).

[14] Z. Marafie, K. Lin, Y. Zhai, and J. Li, "Proactive FinTech: Using intelligent IoT to deliver positive InsurTech feedback", 2018 IEEE 20th Conference on Business Informatics (CBI), vol. 02, pp. 72-81, 2018.

[15] P. Marano, "Navigating InsurTech: The digital intermediaries of insurance products and customer protection in the EU", Maastricht Journal of European and Comparative Law, vol. 26 (2), pp. 294-315, 2019. DOI: 10.1177/1023263X19830345. 